\title{
Synthesis and Spectral Characterization of Praseodymium(III) Complex with New Amino Acid-Based Azo Dye
}

\author{
Man Singh and Sushma Anant \\ Chemistry Research Lab, Deshbandhu College, University of Delhi, New Delhi 110019, India \\ Correspondence should be addressed to Sushma Anant, sushma.aanant@gmail.com \\ Received 24 November 2011; Revised 4 January 2012; Accepted 4 January 2012 \\ Academic Editor: Alvaro J. Pardey \\ Copyright ( $) 2012$ M. Singh and S. Anant. This is an open access article distributed under the Creative Commons Attribution \\ License, which permits unrestricted use, distribution, and reproduction in any medium, provided the original work is properly \\ cited. \\ A new Praseodymium (Pr) (III) complex has been synthesized and characterized by using a new amino acid-based (leucine) azo \\ dye such as N,N-dimethylazoleucine (L1) and 1,10 phenanthroline (L2). Reaction of Pr(III) ion with L1 and L2 in $1: 2: 1$ ratio in \\ alcoholic medium has been carried out with general formula $\left[\mathrm{Pr}(\mathrm{L} 1)_{2}(\mathrm{~L} 2)\left(\mathrm{H}_{2} \mathrm{O}\right)_{2}\right]$. Elemental analysis, comparative FT-IR, and \\ ${ }^{1}$ HNMR spectral studies of $\operatorname{Pr}(\mathrm{III})$ complex with ligands have been shown in this paper.
}

\section{Introduction}

Lanthanide complexes attract a growing interest in material science due to their optical and magnetic properties. Special interests are those in which ligands play a role of intramolecular sensitizer for lanthanide luminescence [1]. Therefore, the choice of ligand remains a crucial point, and molecules containing aromatic moieties are very often found to be good sensitizers for lanthanide ions. In the last decade, the new materials based on lanthanide complexes have been studied with particular interest for applications as highly efficient light conversion molecular devices. They can be used in wide range of processes and new technologies, such as fluorescent lighting, electroluminescence color displays, luminescent labels in bioaffinity assays, bioinorganic sensors, and high technology optics and optoelectronic applications [2-8]. Weissman in 1942 reported that lanthanide can be improved by using an intramolecular energy transfer, the antenna effect [1]. Common used ligands are $\beta$-diketonates and noncharged adducts like 1,10 phenanthroline or 2,2bipyridine.

A new azo dye has been synthesized, named, N,NDimethylazoleucine, composed of leucine $\left(\mathrm{NH}_{2} \mathrm{CH}-\right.$ $\left.\left(\mathrm{CH}_{2} \mathrm{CH}\left(\mathrm{C}_{2} \mathrm{H}_{6}\right)\right) \mathrm{COOH}\right)$ as basic moiety and 1,2-dimethyl aniline $\left(\mathrm{C}_{6} \mathrm{H}_{5} \mathrm{~N}\left(\mathrm{CH}_{3}\right)_{2}\right)$ and its $\operatorname{Pr}(\mathrm{III})$ complex with 1,10 phenanthroline (heterocyclic compound) (L2) adduct to assess the possibilities of $\operatorname{Pr}(\mathrm{III})$ complexes formation and spectral changes that occur due to complexation.

\section{Experimental}

2.1. Chemicals and Measurements. Elemental analysis was performed with Perkin Elmer 2400 (SAIF Chandigarh, Punjab University). FT-IR spectra were recorded with $\mathrm{KBr}$ pellets in 4000 to $400 \mathrm{~cm}^{-1}$ on Nicoletet Protese 460 Spectrograph EFT (IIT Delhi). ${ }^{1} \mathrm{H}$ NMR spectra were recorded with DMSO- $\mathrm{d}_{6}$ medium on DPX-dix $300 \mathrm{MHz}$ Bruker Avance spectrometer using TMS as an internal reference from 0 to $9 \delta \mathrm{ppm}$ (IIT Delhi). Thermogravimetric analysis (TGA) was recorded with F-2nd Perkin Elmer F-second Pyrif Diamond in nitrogen atmosphere (IIT Delhi). Conductivities were measured with digital conductivity meter Model 621E (ranging from 0 to $1999 \mu \mathrm{S}$, with resolution $1 \mu \mathrm{S}$ ).

The lanthanide (Pr, Nd, Ho, and Er) oxides (99.9\%) were procured from Acros Organics, India. The 1,10 Phenanthroline monohydrate $(99.9 \%)$, glycine $(99 \%)$, sodium nitrite (99\%), and N,N-dimethylaniline (99\%) were purchased from E. Merck, India. The solvents were of AR or spectroscopic grade, and the chemicals were used as received. 
(1)
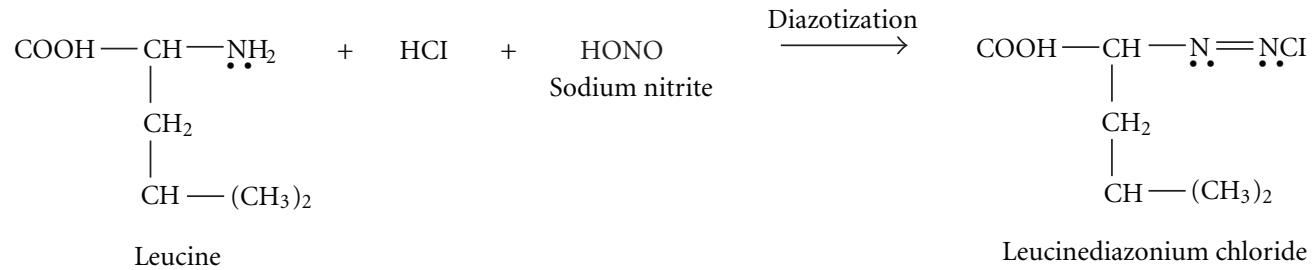

Leucinediazonium chloride

(2)

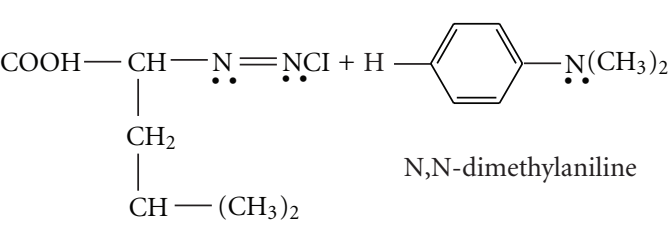

Leucinediazonium chloride<smiles>CC(C)CC(N=Nc1ccc(N(C)C)cc1)C(=O)O</smiles>

$\mathrm{N}, \mathrm{N}$-dimethylazoleucine

$\mathrm{L} 1$
(3)<smiles>CC(C)CC(N=Nc1ccc(N(C)C)cc1)C(=O)O</smiles>

L1

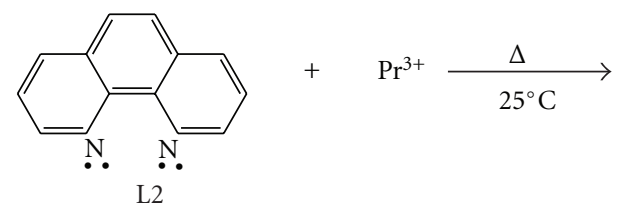

(1,10 phenanthroline)

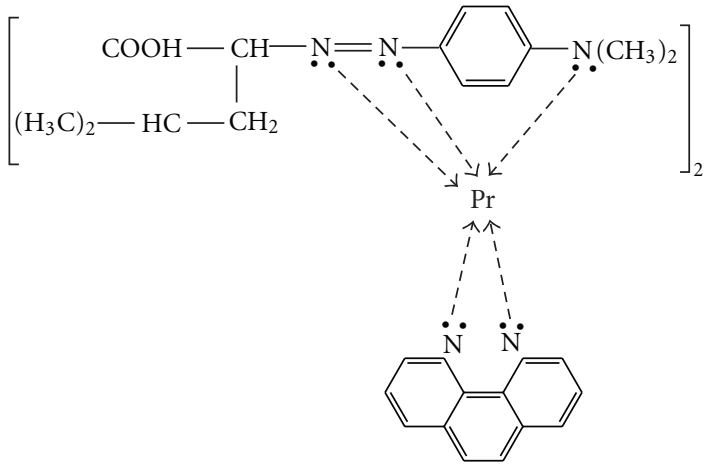

Praseodymium (III) complex

Scheme 1: Synthesis of N,N-dimethylazoleucine ligand (L1) and $\operatorname{Pr}(\mathrm{III})$ complex.

2.2. Preparation of Praseodymium Chloride. Lanthanides(III) chlorides (praseodymium(III) chlorides) $\left(\mathrm{PrCl}_{3} \cdot 7 \mathrm{H}_{2} \mathrm{O}\right)$ with $\mathrm{pH}$ from 4 to 6 were obtained from respective $\operatorname{Pr}(\mathrm{III})$ oxides by heating with $10 \times 10^{-3} \mathrm{dm}^{3}$ AR-hydrochloric acid $(\mathrm{HCl})$ $(1: 1)$ at $70^{\circ} \mathrm{C}$. The resulting solution was rotoevaporated, precipitated, and recrystallized in methanol [9].

2.3. Preparation of Azo Dye (L1) Ligand. Synthesis of azo compound was consisting of two processes: diazotization and coupling (Scheme 1).
2.3.1. Diazotization. $7.1 \mathrm{~g}$ of leucine $\left(\mathrm{NH}_{2} \mathrm{CH}\left(\mathrm{CH}_{2} \mathrm{CH}-\right.\right.$ $\left.\left.\left(\mathrm{C}_{2} \mathrm{H}_{6}\right)\right) \mathrm{COOH}\right)$ was dissolved with $50 \mathrm{~mL}$ Millipore water and warmed till a complete dissolution. Now new solution of sodium nitrite $\left(\mathrm{NaNO}_{2}\right)(2 \mathrm{~g})$ with $10 \mathrm{~mL} \mathrm{H} \mathrm{H}_{2} \mathrm{O}$ was added in the above reaction mixture and then allowed to cool in ice bath where temperature was maintained between 0 and $5^{\circ} \mathrm{C}$. Cold diluted $\mathrm{HCl}$ solution $(28 \mathrm{~mL})$ was added dropwise in reaction mixture (in ice bath) with continuous stirring to complete a diazotization process. 
TABLE 1: Elemental analysis data of L1 and Pr(III) complex.

\begin{tabular}{lcccccc}
\hline Compounds & \multicolumn{3}{c}{ Found $\%$} & \multicolumn{3}{c}{ Calculated \% } \\
& $\mathrm{C}$ & $\mathrm{H}$ & $\mathrm{N}$ & $\mathrm{C}$ & $\mathrm{H}$ & $\mathrm{N}$ \\
\hline $\mathrm{L} 1$ & 61.88 & 7.76 & 14.59 & 63.86 & 8.03 & 15.96 \\
$\operatorname{Pr}(\mathrm{L} 1)_{2} \mathrm{~L} 2 \mathrm{H}_{2} \mathrm{O}$ & 55.94 & 5.23 & 12.34 & 57.44 & 6.51 & 13.65 \\
\hline
\end{tabular}

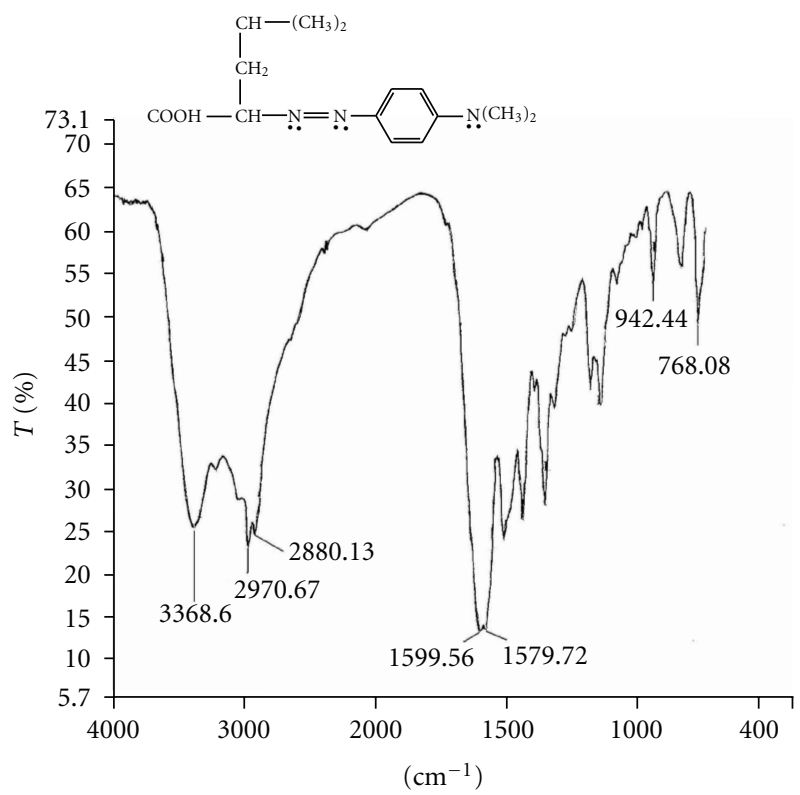

FIGURE 1: FT-IR spectra of L1.

2.3.2. Coupling. Again a cold solution of $\mathrm{N}, \mathrm{N}$-dimethylaniline $\left(\mathrm{C}_{6} \mathrm{H}_{6} \mathrm{~N}\left(\mathrm{CH}_{3}\right)_{2}\right)(4 \mathrm{~mL})$ in dilute $\mathrm{HCl}$ was added to the above-prepared reaction mixture and shook thoroughly for few mins followed by an addition of $20 \% \mathrm{NaOH}(30 \mathrm{~mL})$. Finally the resultant reaction mixture was heated to $60^{\circ} \mathrm{C}$ with an addition of $8 \mathrm{~g} \mathrm{NaCl}$ and kept in ice bath $\left(0-5^{\circ} \mathrm{C}\right)$ for 3-4 $\mathrm{h}$ to obtain precipitate. A dark brown colored precipitate (L1) was filtered and gently washed several times with cold water till it was free completely of all impurities. Then the precipitate was dried at room temperature and then stored in vacuum desiccator filled with $\mathrm{P}_{2} \mathrm{O}_{5}$.

\subsection{Preparation of 1,10 Phenanthroline (L2) Ligand. L2} $\left(\mathrm{C}_{12} \mathrm{H}_{8} \mathrm{~N}_{2}\right)$ is used directly without any further purification.

2.5. Preparation of $\operatorname{Pr}(I I I)$ Complex. The $\operatorname{Pr}(\mathrm{III})$ complex was synthesized by reaction of $\mathrm{PrCl}_{3} \cdot n \mathrm{H}_{2} \mathrm{O}(1 \mathrm{~mol})$ with $\mathrm{L} 1$ (2 mol) and $\mathrm{L} 2(1 \mathrm{~mol})$ in $\mathrm{L} n: \mathrm{L} 1: \mathrm{L} 2$ molar ratios equal to of $1: 2: 1$. The ethanolic solutions of L1 $(20 \mathrm{~mL})$ and L2 $(20 \mathrm{~mL})$ were added one by one with continuous stirring to saturated ethanolic solution of $\mathrm{PrCl}_{3} \cdot n \mathrm{H}_{2} \mathrm{O}$. Then the reaction mixture was stirred with an electromagnetic stirrer at $25^{\circ} \mathrm{C}$ till its volume was reduced to half of its original volume by continuous rotoevaporation. Dark brown colored $\operatorname{Pr}(\mathrm{III})$ complex precipitate was obtained and dried at room temperature and kept for 9-10 days. After crystallization

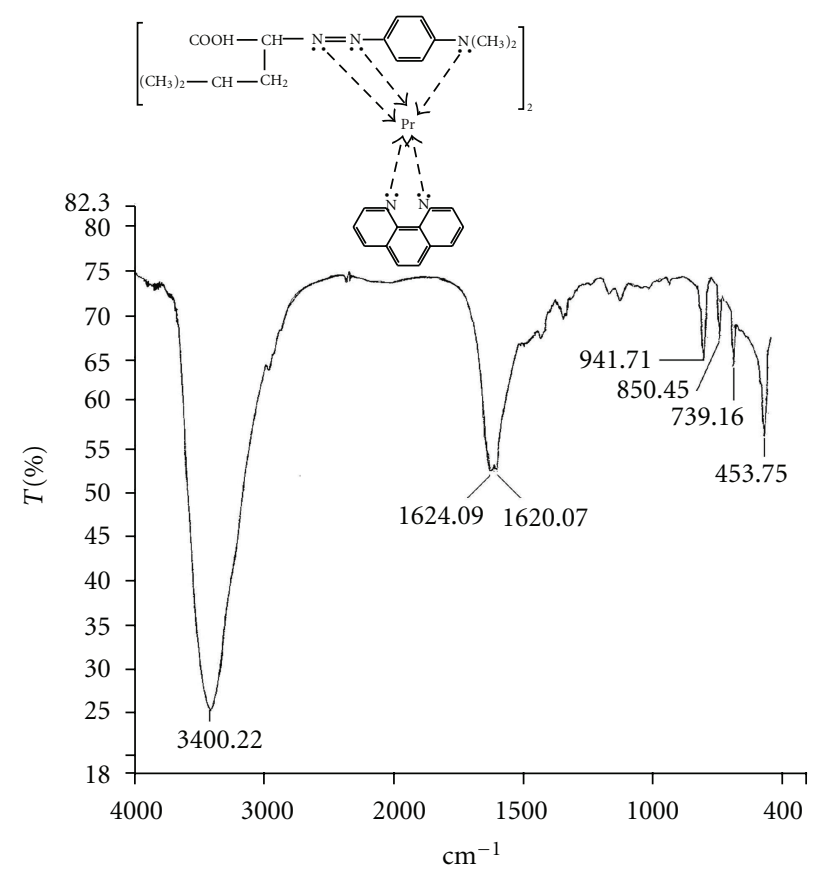

FIGURE 2: FT-IR spectra of Pr(III) complex with L1 and L2.

precipitates were washed with distilled water and dried in vacuum desiccator to contents weight.

\section{Result and Discussion}

The $\operatorname{Pr}(\mathrm{III})$ complex is a dark brown colored solid, partially soluble in water, highly soluble in ethanol, DMSO and DMF solvents. The elemental analysis data of the L1 and its $\operatorname{Pr}(\mathrm{III})$ complex given in Table 1 is consistent with the calculated results from the empirical formula. The electric conductance measurement in DMF solvent shows the nonelectrolytic nature of $\operatorname{Pr}(\mathrm{III})$ complex. The reactions of L1 and L2 with Pr ions are mentioned in Scheme 1.

3.1. FT-IR. The FT-IR spectra of $\mathrm{L} 1$ and $\operatorname{Pr}(\mathrm{III})$ complex (Figures 1 and 2) ranged $4000-400 \mathrm{~cm}^{-1}$ with broad stretching vibrations of all characteristic functional moieties of ligands (L1 and L2), revealing their direct interaction to metal ions (Table 2). On the other hand, spectra of free ligand L1 generally cause sharp signals (Figure 1).

Vibrational spectra of ligand L1 shows a broad vibrational spectrum at $3368.60 \mathrm{~cm}^{-1}$, due to $\mathrm{OH}$-stretching vibration of carboxylic group (Figure 1). Bands at $2970.67 \mathrm{~cm}^{-1}$ and $2880.13 \mathrm{~cm}^{-1}$ are due to asymmetric and symmetric $v_{\mathrm{C}-\mathrm{H}}$ stretching vibrations [10]. A strong and 
TABLE 2: Stretching frequencies $\left(\mathrm{cm}^{-1}\right)$ of functional groups of L1 and $\operatorname{Pr}(\mathrm{III})$ complex.

\begin{tabular}{|c|c|c|c|c|c|c|c|}
\hline Ligands/complexes & $\mathrm{O}-\mathrm{H}$ & $\mathrm{C}=\mathrm{O}$ & $\mathrm{N}=\mathrm{N}$ & $\mathrm{C}-\mathrm{N}$ & Aromatic group & $\mathrm{C}=\mathrm{C}$ & $\mathrm{Pr}-\mathrm{N}$ \\
\hline L1 & 3368.60 & 1599.56 & 1597.72 & 924.44 & $\begin{array}{c}1508.56,1435.13 \\
1351.09,1314.28\end{array}$ & 748.08 & \\
\hline $\operatorname{Pr}$ & 3400.22 & 1624.09 & 1620.07 & 941.71 & $\begin{array}{c}1518.46,1436.01 \\
1349.98\end{array}$ & 739.16 & 453.75 \\
\hline
\end{tabular}

TABle 3: Proton magnetic resonance data (chemical shift $\delta$ in ppm) of L1, L2, and $\operatorname{Pr}(\mathrm{III})$ complex.

\begin{tabular}{|c|c|c|c|c|c|c|}
\hline Ligands/complexes & $\mathrm{Ha}, \mathrm{Hp}$ & $\mathrm{Hb}$ & $\mathrm{Hc}$ & $\mathrm{Hd}$ & $\mathrm{Hd}, \mathrm{Hs}, \mathrm{Ht}$ & $\mathrm{He}-\mathrm{Hh}$ \\
\hline L1 & 2.47 & $5.34-5.51$ & $5.97-7.19$ & $5.34-5.51$ & $3.06-3.80$ & \\
\hline L2 & & & & & & $7.63-9.19$ \\
\hline $\operatorname{Pr}$ & 2.59 & $5.80-5.96$ & $6.42-7.61$ & 3.443 & $3.12-3.80$ & 9.71 \\
\hline
\end{tabular}

broad absorption bands have been noticed in L1 spectra at $1599.56 \mathrm{~cm}^{-1}$ and $1579.72 \mathrm{~cm}^{-1}$, due to overlap of $\nu_{\mathrm{C}=\mathrm{O}}$ and $v_{\mathrm{N}=\mathrm{N}}$ stretching mode of carboxyl group and azo group, respectively. Multiple and dominant peaks from $1508.56 \mathrm{~cm}^{-1}$ to $1314.28 \mathrm{~cm}^{-1}$ supported the presence of aromatic moiety in L1, and an absorption peak at $748.00 \mathrm{~cm}^{-1}$ indicated $\mathrm{C}-\mathrm{H}$ out of plane-bending vibration of disubstituted benzene ring. A sharp peak at $942.44 \mathrm{~cm}^{-1}$ is due to $\mathrm{C}-\mathrm{N}$ group in $\mathrm{L} 2$. Vibrational spectrum of $\operatorname{Pr}$ (III) complex is quite different as compared to L2 due to a very strong and broad peak at $3400.22 \mathrm{~cm}^{-1}$, with $\nu_{\mathrm{O}-\mathrm{H}}$ stretching vibration of coordinated water $(\mathrm{OH})$ and protonated $\mathrm{OH}$ of carboxylic group. As there is very strong interlinked hydrogen bonding, it can be said that the peak assignment for water and that of $\mathrm{OH}$ of carboxylic group is due to overlapping of their respective groups (Figure 2). Disappearance of $v_{\mathrm{C}-\mathrm{H}}$ stretching vibration of methyl group inferred the complex formation. A strong and broad absorption peaks have been noticed in L1 spectra at $1599.56 \mathrm{~cm}^{-1}$ and $1579.72 \mathrm{~cm}^{-1}$, which can be due to overlap of $v_{\mathrm{C}=\mathrm{O}}$ and $\nu_{\mathrm{N}=\mathrm{N}}$ stretching mode of carboxyl group and azo group, respectively. Now, shifting of peaks for $\mathrm{C}=\mathrm{O}$ and $\mathrm{N}=\mathrm{N}$ stretching vibrations at $1624.09 \mathrm{~cm}^{-1}$ and $1620.67 \mathrm{~cm}^{-1}$ from its original peak frequencies in L1 spectra found to be characteristic supported the $\operatorname{Pr}(\mathrm{III})$ complex formation. Diminishing of bands at $1518.46 \mathrm{~cm}^{-1}$ to $1349.98 \mathrm{~cm}^{-1}$ of aromatic group supported Pr-ligand coordination bond formation. A characteristic $\mathrm{C}-\mathrm{H}$ out of plane bending vibration is seen at $850.45 \mathrm{~cm}^{-1}$, indicating the presence of L2 in complex. A peak at $453.75 \mathrm{~cm}^{-1}$ indicates the $\operatorname{Pr}-\mathrm{N}$ [11] coordination bond formation from L1 and L2 to Pr ion, which is constructive support for new coordination complex formation.

3.2. ${ }^{1} \mathrm{H}$ NMR. The ${ }^{1} \mathrm{H}$ NMR of $\mathrm{L} 1$ or azo compound and $\operatorname{Pr}($ III) complex has been recorded from $\delta 0$ to $10 \mathrm{ppm}$ with DMSO- $\mathrm{d}_{6}$ to confirm the $\operatorname{Pr}$ (III) complex formulation. Present paper will describe all comparative and characteristics peaks signals of ligands and chemicals shifts appeared due to $\operatorname{Pr}(\mathrm{III})$ complex formation in Table $3 .{ }^{1} \mathrm{H}$ NMR spectra of L1 and $\operatorname{Pr}(\mathrm{III})$ complex are described in Figures 3 and 4 , respectively.

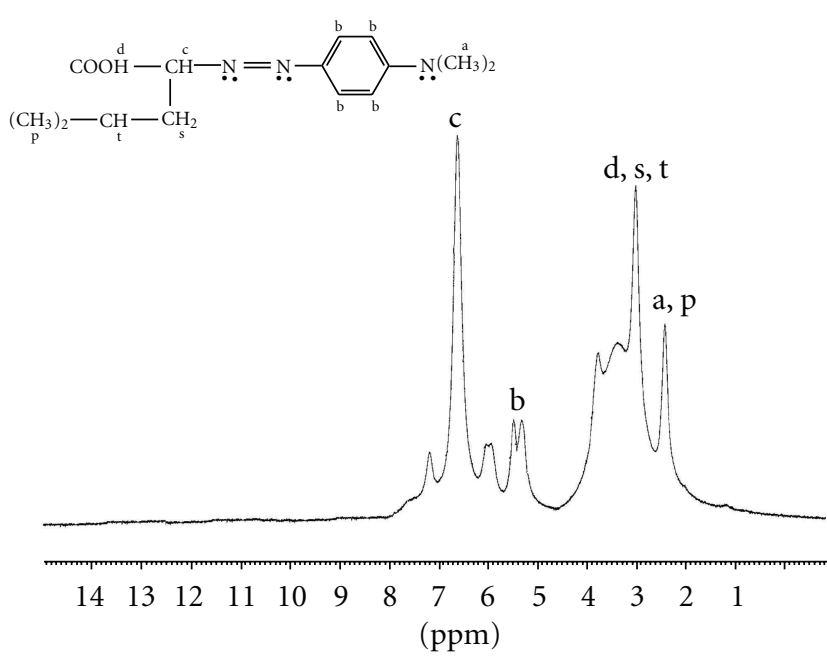

Figure $3:{ }^{1} \mathrm{H}$ NMR spectra of L1.

${ }^{1} \mathrm{H}$ NMR spectra of L1 show resonating protons signals in four sets of signals between $\delta 0-10 \mathrm{ppm}$. First upfield signal appears as a singlet at $\delta 2.47 \mathrm{ppm}(J=0.85 \mathrm{~Hz})$ for $\mathrm{Ha}$ and $\mathrm{Hp}$ protons of four methyl group in ligand L1. The second multiplet resonate in upfield between $\delta 3.06$ and $3.80 \mathrm{ppm}$ $(J=3.80 \mathrm{~Hz})$ assigned to $\mathrm{Hd}(\mathrm{COOH}), \mathrm{Hs}\left(\mathrm{CH}_{2}\right)$, and $\mathrm{Ht}(\mathrm{CH})$, as it has concluded that $\mathrm{Hd}, \mathrm{Hs}$, and $\mathrm{Ht}$ protons required approximately same resonating field so a broad multiplet is appeared. Third signal is a downfield doublet with signals between $\delta 5.34$ and $5.51 \mathrm{ppm}(J=0.89 \mathrm{~Hz})$ for $\mathrm{Hb}$ of aromatic ring of L1. Forth and last downfield quartet at $\delta 5.97 \mathrm{ppm}(J=0.25 \mathrm{~Hz}), 6.09(J=0.25 \mathrm{~Hz}), \delta 6.65 \mathrm{ppm}$ $(J=1.31 \mathrm{~Hz})$, and $\delta 7.19 \mathrm{ppm}(J=0.33 \mathrm{~Hz})$ appeared due to $\mathrm{Hc}(\mathrm{CH})$ (Figure 3 ).

Unlike proton spectra of L1 signals which appeared in four sets, $\operatorname{Pr}$ (III) complex has shown similar trends of signals in its spectra but mainly five sets of signals, and all are shifted to downfield indicating $\operatorname{Pr}$ (III) complex formation. Downfield shifting of first upfield singlet to $\delta 2.59 \mathrm{ppm}(J=$ $0.96 \mathrm{~Hz}$ ) for $\mathrm{Ha}$ and $\mathrm{Hp}$ protons of four methyl groups of L1. Again a second set of signals like for L1, appeared as multiplet, infers the complex formation by indicating signals 
TABLE 4: Thermogravimetric analysis data (Weight loss\%) of $\operatorname{Pr}(\mathrm{III})$ complex.

\begin{tabular}{lcccc}
\hline \multirow{2}{*}{ Complexes } & Temperature $\left({ }^{\circ} \mathrm{C}\right)$ & \multicolumn{2}{c}{ Weight loss $\%$} & Constituents eliminated \\
\hline \multirow{2}{*}{$\operatorname{Pr}(\mathrm{L} 1)_{2} \mathrm{~L}_{2} \mathrm{H}_{2} \mathrm{O}$} & 123.5 & $0.55 \%$ & Calculated $\%$ & Five water molecules \\
& 296.5 & $12.44 \%$ & $1.60 \%$ & One L2 molecule \\
\hline
\end{tabular}

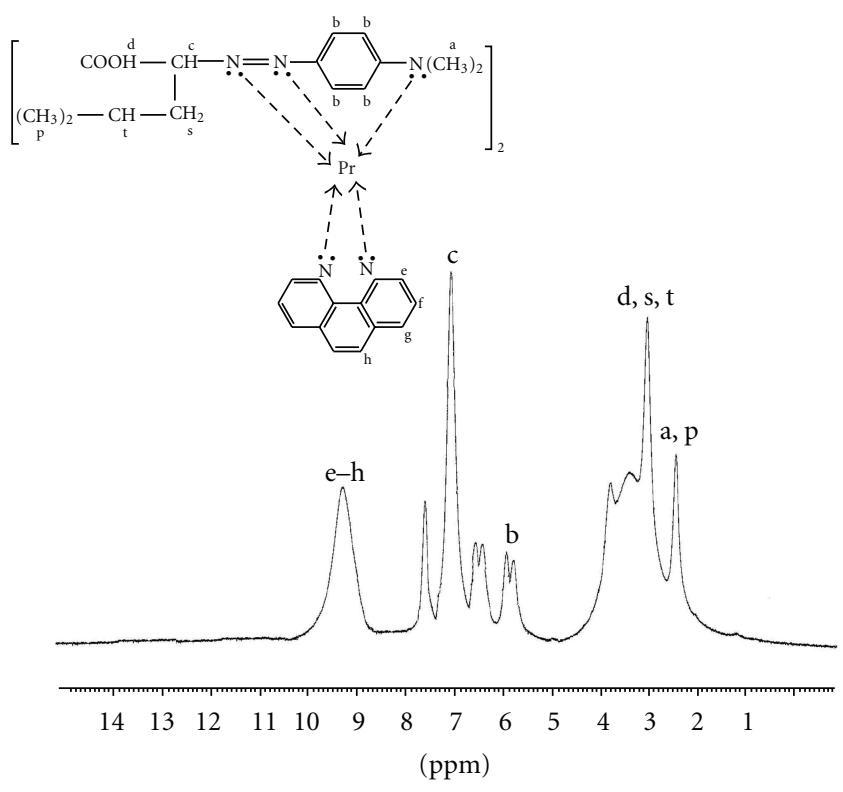

FIgURE 4: ${ }^{1} \mathrm{H}$ NMR spectra of Pr(III) complex with L1 and L2.

at $\delta 3.12 \mathrm{ppm}(J=1.24 \mathrm{~Hz}), \delta 3.42 \mathrm{ppm}(J=0.89 \mathrm{~Hz})$, and $\delta 3.80 \mathrm{ppm}(J=1.12 \mathrm{~Hz})$. These are assigned to three set of protons like $\mathrm{Hd}(\mathrm{COOH}), \mathrm{Hs}\left(\mathrm{CH}_{2}\right)$, and $\mathrm{Ht}(\mathrm{CH})$. Third signal is a downfield doublet with signals between $\delta 5.80-$ $5.96 \mathrm{ppm}(J=1.02 \mathrm{~Hz})$ for $\mathrm{Hb}$ of aromatic ring, and forth and downfield shifted quartet at $\delta 6.42 \mathrm{ppm}(J=0.29 \mathrm{~Hz})$, $6.69 \mathrm{ppm}(J=0.30 \mathrm{~Hz}), \delta 7.07 \mathrm{ppm}(J=1.34 \mathrm{~Hz})$, and $\delta$ $7.61 \mathrm{ppm}(J=0.56 \mathrm{~Hz})$ are due to $\mathrm{Hc}(\mathrm{CH})$ like L1. Fifth and last downfield broad singlet at $\delta 9.71 \mathrm{ppm}(J=1.00 \mathrm{~Hz})$ assigned to L2 protons ( $\mathrm{He}-\mathrm{Hh}$ ) with the coordination of L2 to metal ion (Figure 4).

Due to electron transfer from nitrogen of L1 and L2 to $\operatorname{Pr}(\mathrm{III})$ ion, many differences in chemical shifts have been noticed and confirmed an expected coordination of metal ligands.

3.3. TGA. The thermogram of $\operatorname{Pr}(\mathrm{III})$ complex $[\mathrm{Pr}(\mathrm{L} 1)(\mathrm{L} 2)-$ $\left(\mathrm{H}_{2} \mathrm{O}\right)$ ] was examined by TGA in the temperature range ambient to $1000^{\circ} \mathrm{C}$ carried out in nitrogen atmosphere by heating at $10^{\circ} \mathrm{C} \mathrm{min}^{-1}$. The thermogram of the $\operatorname{Pr}$ (III) complex shows stepwise decomposition and reveals the presence of water molecules in $\operatorname{Pr}$ (III) complex (Table 4). $\operatorname{Pr}(\mathrm{III})$ complex shows an inflexion point at $123.5^{\circ} \mathrm{C}$ with a weight loss of $0.55 \%$. Representing the removal of one water molecules coordinated to Pr ion with weight loss compared to calculated $1.60 \%$. The second inflexion point appeared at $296.5^{\circ} \mathrm{C}$ and represents expulsion of one coordinated
1,10 phenanthroline molecule. The observed weight loss at this temperature is $15.96 \%$, which is found equivalent to calculated weight loss $12.44 \%$ for one unit of L2.

\section{Conclusion}

A new leucine-based azo dye and its complex with $\operatorname{Pr}(\mathrm{III})$ were synthesized and characterized successfully. FT-IR spectra supported praseodymium ion coordination with six and two nitrogen atoms of two tridentate L1 and one bidentate L2 ligands, respectively, with specific stretching frequencies at $453.75 \mathrm{~cm}^{-1}$, of nitrogen bonding with metal ion. Prominent singlet between $\delta 3.12$ and $3.80 \mathrm{ppm}$ in ${ }^{1} \mathrm{H}$ NMR showed a presence of a intact hydroxyl group $(\mathrm{OH})$ of carboxyl $(\mathrm{COOH})$ moiety of the L1 with Pr(III) complex. Thermogravimetric analysis supported the coordination of one water molecules with $\operatorname{Pr}($ III) complex. The molecular structure of metal complex with the ligands has been well established with several techniques described in this paper.

\section{References}

[1] S. I. Weissman, "Intramolecular energy transfer the fluorescence of complexes of Europium," The Journal of Chemical Physics, vol. 10, no. 4, pp. 214-217, 1942.

[2] J.-M. Lehn, Supramolecular Chemistry, V. Balzani, Ed., Reidel, Dordrecht, The Netherlands, 1987.

[3] J.-C. G. Bunzli, Lanthanide Probes in Life, Medical and Environmental Sciences, G. R. Chopin, J.-C. G. Bunzli, Eds., chapter 7, Elsevier, Amsterdam, The Netherlands, 2005.

[4] J. A. Fernandes, R. A. Sá Ferreira, M. Pillinger et al., "Investigation of europium(III) and gadolinium(III) complexes with naphthoyltrifluoroacetone and bidentate heterocyclic amines," Journal of Luminescence, vol. 113, no. 1-2, pp. 50-63, 2005.

[5] S. P. Vila Nova, H. J. Batista, S. Alves Jr. et al., "Theoretical and experimental photophysical studies of the tris $(4,4,4-$ trifluoro-1-(1-naphthyl)-1,3-butanedionate) (2,2'-bipiridyl)europium(III)," Journal of Luminescence, vol. 118, no. 1, pp. 83-90, 2006.

[6] P. Gawryszewska, L. Jerzykiewicz, M. Pietraszkiewicz, J. Legendziewicz, and J. P. Riehl, "Photophysics and crystal structure of a europium(III) cryptate incorporating 3,3'biisoquinoline-2,2' -dioxide," Inorganic Chemistry, vol. 39, no. 23, pp. 5365-5372, 2000.

[7] J. Legendziewicz, V. Tsaryuk, V. Zolin, E. Lebedeva, M. Borzechowska, and M. Karbowiak, "Optical spectroscopy and magnetic studies of dimeric europium capronate with 1,10phenanthroline," New Journal of Chemistry, vol. 25, no. 8, pp. 1037-1042, 2001.

[8] J. Legendziewicz, "Spectroscopy of nanometer-range media and mixed lanthanide $\operatorname{Ln} \beta$ 3L compounds: their applications 
perspectives," Journal of Alloys and Compounds, vol. 341, no. 1-2, pp. 34-44, 2002.

[9] L. Huang, L. P. Zhang, and L. P. Jin, "Hydrothermal synthesis and structural characterization of new lanthanide coordination polymers with pimelic acid and 1,10-phenanthroline," Journal of Molecular Structure, vol. 692, no. 1-3, pp. 169-175, 2004.

[10] J. Umemura, D. G. Cameron, and H. H. Mantsch, "A Fourier transform infrared spectroscopic study of the molecular interaction of cholesterol with 1,2-dipalmitoyl-sn-glycero-3phosphocholine," Biochimica et biophysica acta, vol. 602, no. 1, pp. 32-44, 1980.

[11] S. K. Sengupta, O. P. Pandey, A. Sinha, and S. Tripathi, "Lanthanum(III) and praseodymium(III) complexes with macrocyclic ligands containing pendant functional groups," Progress in Crystal Growth and Characterization of Materials, vol. 45 , no. $1-2$, pp. 37-42, 2002. 


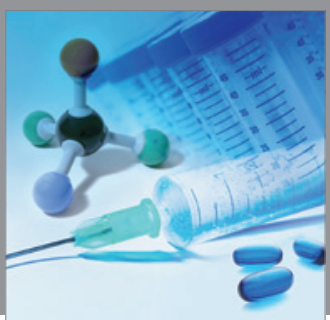

International Journal of

Medicinal Chemistry

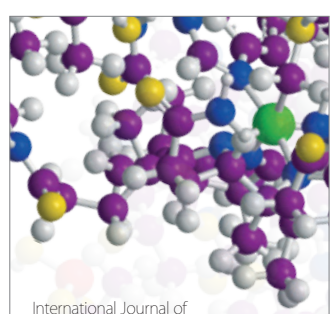

Carbohydrate Chemistry

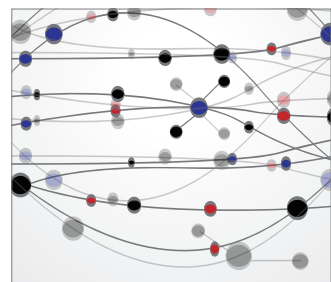

The Scientific World Journal
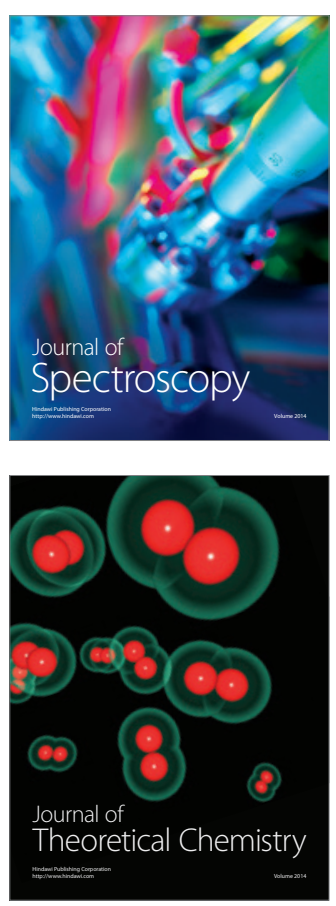
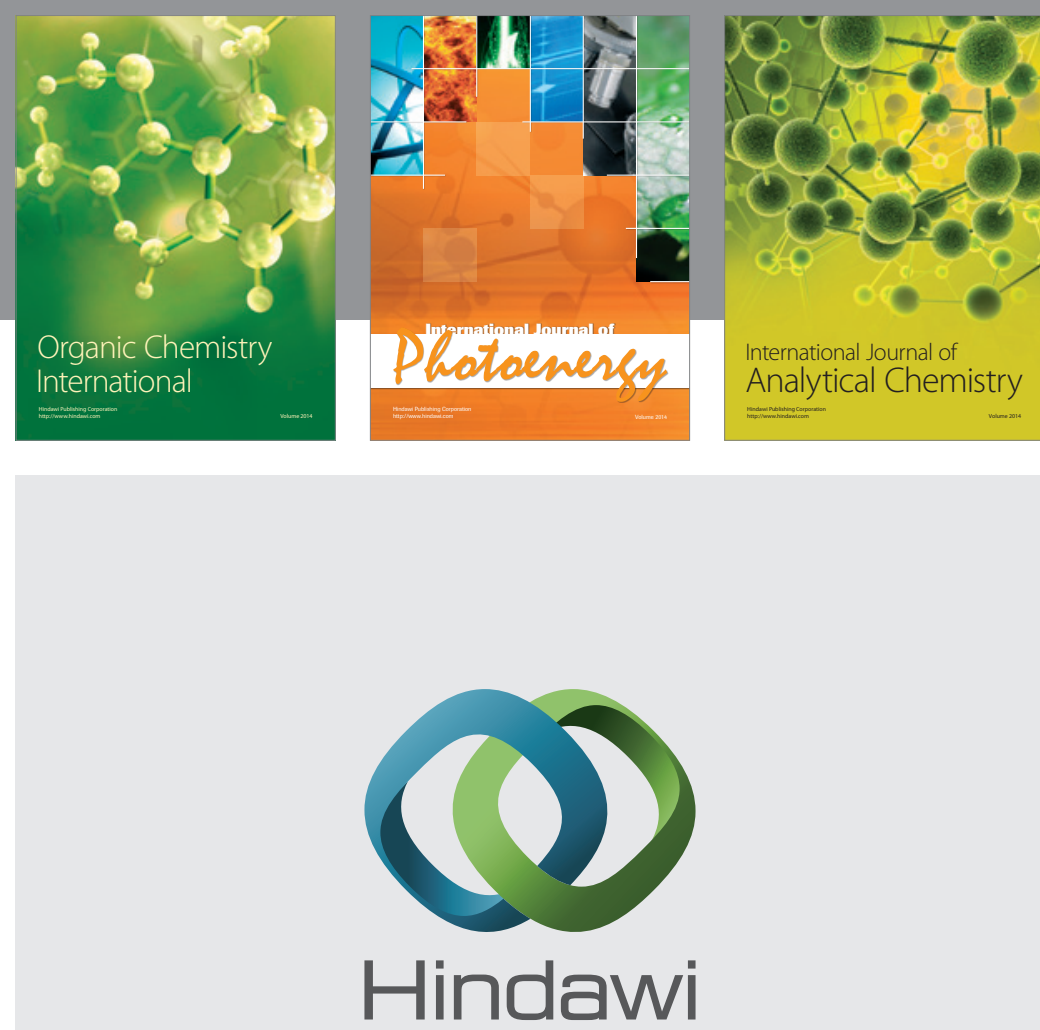

Submit your manuscripts at

http://www.hindawi.com
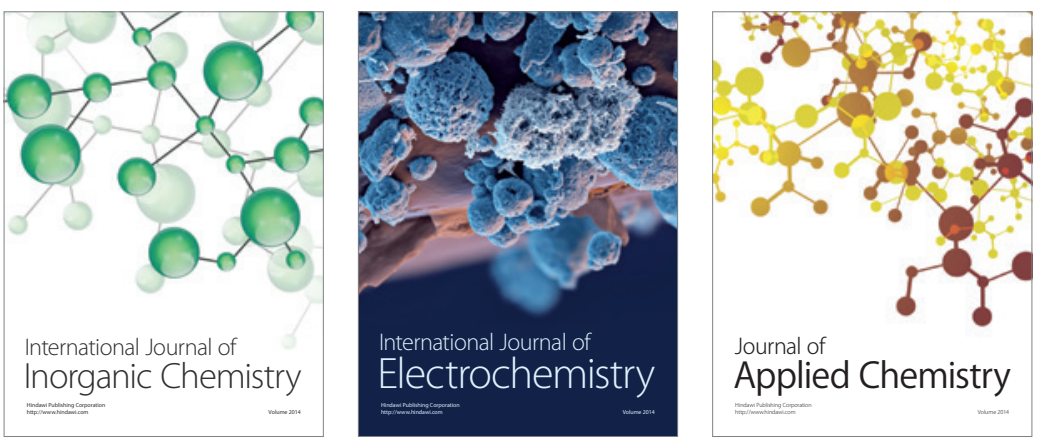

Journal of

Applied Chemistry
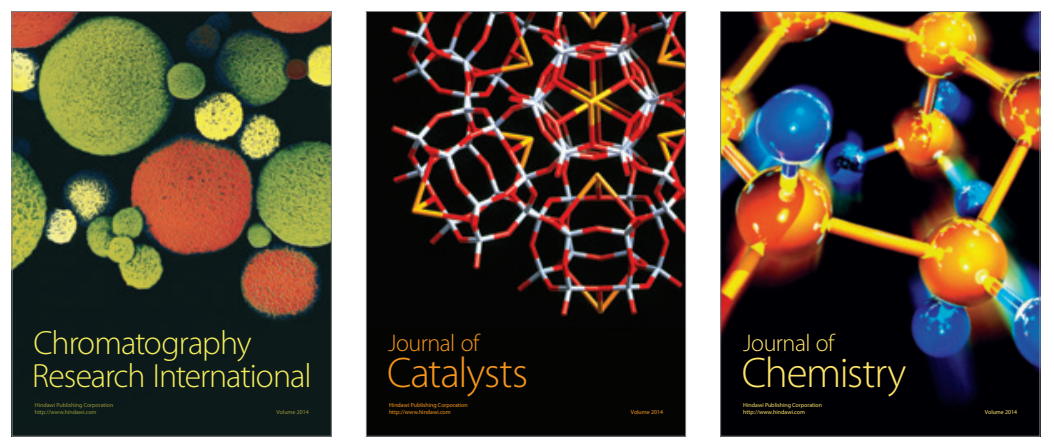
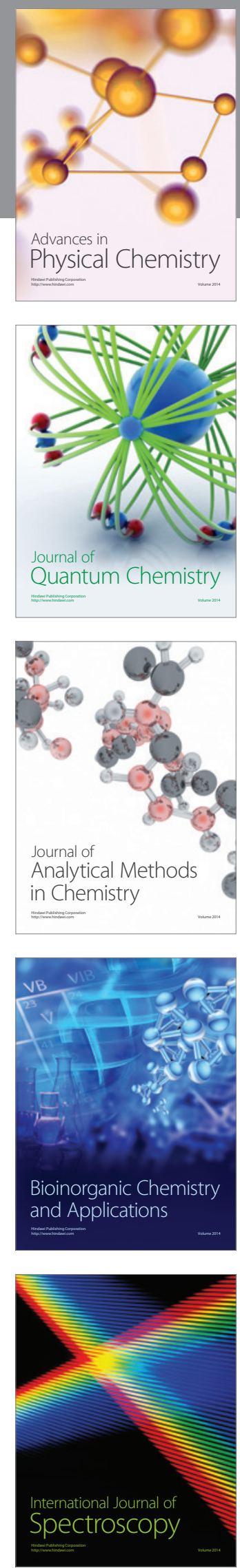